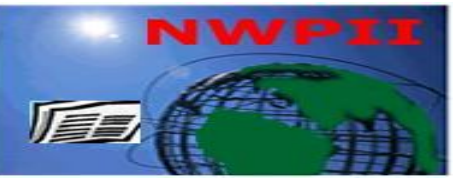

American Journal of Biomedical Sciences

ISSN: 1937-9080

nwpii.com/ajbms

\title{
Modulatory effects of Selenium on Spermatogenesis: Involvement of transcription factors CREB and CREM
}

\author{
Pavitra Ranawat and M.P. Bansal*
}

Department of Biophysics, Panjab University, Chandigarh 160014, India

* Corresponding Author:

Dr M P Bansal

Department of Biophysics

Panjab University

Chandigarh, 160014

India

Tel : 0172-2534120, Fax : 0172-2534118

E-mail: mpbansal@pu.ac.in

Received: 2 May 2010; | Revised: 8 June 2010; | Accepted: 12 June 2010

\begin{abstract}
In the testicular compartment, cAMP response element binding protein (CREB) and cAMP response element modulator (CREM) transcription factors are important transducers of hormonal signals into the induction of gene expression. Selenium (Se) is essential for male fertility. It has been shown earlier in our lab that selenite modulates Nuclear Factor $\kappa B$, Activator Protein-1 and Stress Activated Protein Kinase pathways in the testicular mileau. Keeping all these in view, the present study was designed to explore further the intracellular pathways involved in spermatogenesis, by analyzing the transcription factors, CREB and CREM under Se status conditions. Also, the levels of Leutinising hormone, Follicle stimulating hormone and Testosterone were monitored to gain insight into the hormonal circuitry involved in the process. Mice were fed yeast based Se deficient, adequate and excess diet for 8 weeks after which they were sacrificed for further analysis. It was seen that Se deficient diet fed animals showed a reduction in testicular Se content alongwith decrease in glutathione peroxidase (GSH-Px) activity. On the other hand Se levels and GSH-Px activity increased in Se excess diet fed group. There was a significant decrease in the mRNA and protein expression of CREB and CREM after Se deficient and excess diet feeding. Also, there was a decrease in the levels of serum Testosterone, LH and FSH alongwith altered testicular histoarchitecture. Thus, spermatogenesis is altered by alteration in Se status. The altered Se status lead to changes in the levels of steroid hormones and the testicular circuitry was hampered. This lead to changes in the basal transcription machinery as demonstrated previously and in addition, the transcription factor CREB and CREM also showed changes in their expression. Thus, the study lead to a conclusion that spermatogenesis is a developmentally regulated program, and is under the control of complex hormonal circuitary which leads to modulation in the various signaling pathways governing cell survival and apoptosis depending upon the physiological conditions.
\end{abstract}

Keywords: Selenium; CREB; CREM; LH; FSH; Testosterone; Spermatogenesis. 


\section{Introduction}

Spermatogenesis is controlled by a complex network of endocrine, paracrine, and autocrine signals. In response to the hypothalamic gonadotropin releasing hormone, the pituitary gland secretes two hormones, luteinizing hormone, and follicle stimulating hormone (FSH) that are involved in the regulation of spermatogenesis. Luteinizing hormone regulates the testosterone secretion by somatic Leydig cells located in the interstitium between seminiferous tubules. FSH acts on Sertoli cells, the only somatic cells inside the seminiferous tubule, by stimulating signaling, gene expression and secretion of peptides and other signaling molecules [1].

In Sertoli cells, the cAMP response element binding protein (CREB) transcription factor is an important transducer of FSH signals into the induction of gene expression [2]. Recent studies suggest that CREB activity in Sertoli cells is required for spermatogenesis; overexpression of a CREB mutant in Sertoli cells in vivo results in apoptosis and elimination of germ cells [3]. Transcription factors of the CREB family are involved in the regulation of gene expression in response to a number of signaling pathways [4]. Activation of gene transcription by CREB is dependent on the phosphorylation of a single serine within the phosphorylation domain ( $\mathrm{P}$ box or kinase-inducible domain, KID) by cAMPdependent protein kinase A, PKA [5]. CREB is expressed in nearly all tissues tested thus far. However, in the testis, investigators have identified a number of novel alternative splice variants that result in the synthesis of mRNAs encoding multiple isoforms of CREB [6;8]. In the rat testis, these alternatively spliced CREB mRNAs are spermatogenic, cycle dependent and expressed during development of the germ and Sertoli cells [9], indicating that the CREB isoforms may be major players in spermatogenesis.

The transcription factor cAMP response element modulator (CREM) is highly expressed in male germ cells [10] and is known to regulate the expression of several post-meiotic genes, such as the transition proteins and protamines, and is likely the key regulator of gene expression during spermatogenesis [11;12]. Targeted disruption of the CREM gene blocks the differentiation program in the first step of spermiogenesis [13;14]. These findings indicate a crucial role of CREM in postmeiotic germ cell differentiation, linking the action of hormonal stimuli to direct regulation of spermatogenesis genes [15].

CREB and CREM belong to the basic domain-leucine zipper (bZip) class of proteins. These factors bind, as homo- or heterodimers, to a DNA sequence known as the cyclic AMP responsive element, which is present in the regulatory region of various target genes [16;17].

Spermatogenesis can be disrupted at various stages in conditions of infertility. Such conditions can have a genetic basis $[18 ; 19]$, can also be due to defects in reproductive hormone production or action [20], or alternatively, be induced by exposure to environmental or chemical toxicants [21;22].

One such essential environmental trace element is selenium (Se) which is present in both prokaryotic and eukaryotic cells. It has been linked to regulatory functions in cell growth, cell survival, cytotoxicity and transformation [23]. Selenium appears to modulate such cellular activities presumably by acting on proteins important for signal transduction [24]. We have previously demonstrated that selenite activates the NF- $\kappa$ B and SAPKs signaling pathways, whereas it represses the AP-1 signaling pathway [25;29].

Also, since the reproductive organ appears to be a priority tissue for Se accumulation [30], previous studies have demonstrated that $\mathrm{Se}$ deficiency and excess conditions give rise to testicular structural [31] and functional disturbances and deficiency of the element causes oxidative stress in the organ due to diminished antioxidant property of this element as a co-factor of GSH-Px [32]. At higher dose levels, Se has various deleterious effects on various organs including testes.

Thus, keeping all these in view, the present study was designed to explore further the intracellular pathways involved in spermatogenesis, by analyzing the transcription factors, CREB and CREM under Se status conditions. Also, the levels of LH, FSH and 
Testosterone were monitored to gain insight into the hormonal circuitry involved in the process.

\section{Materials and Methods}

\subsection{Chemicals}

Sodium selenite $\left(\mathrm{Na}_{2} \mathrm{SeO}_{3}\right), \quad 2,3-$ diaminonapthalene (DAN), Agarose, Ethidium bromide and Proteinase $\mathrm{K}$ were purchased from Sigma-Aldrich (St. Louis, MO, USA). TRIreagent and one-step RT-PCR kit were obtained from Molecular Research Centre (Inc. Cincinnati; Ohio) and QIAGEN, respectively. Oligonucleotides were synthesized by SigmaAldrich. Molecular biology grade chemicals for RNA isolation e.g. chloroform, isopropanol, ethanol and formaldehyde were purchased from Amresco, Ohio (USA)

Antibody against CREB and CREM were purchased from Santa Cruz Biotechnology, Santa Cruz, CA (USA), peroxidase conjugated antirabbit secondary antibody and anti-mouse $\beta$-actin were purchased from Sigma-Aldrich, St Louis (USA). All other chemicals and reagents used in the present study were of analytical grade and were procured from the Indian manufacturers.

\subsection{Animal procurement and treatment schedule}

Male Balb/c mice in the weight range of 20$25 \mathrm{~g}$ were used in the present study. Animals were procured from the Central Animal House, Panjab University, Chandigarh (India). They were housed in a standard animal facility under controlled temperature and 12/12 hr light/dark cycle with food and water provided ad libitum. The proposed study was cleared from the Instituitional Animal Ethics Committee.

To make different Se status animals viz. $0.02 \mathrm{ppm}, 0.2 \mathrm{ppm}$ and $1 \mathrm{ppm}$, in different groups (Group I, II and III respectively), the mice were kept on yeast-based diet. The yeast-based diet usually contains $0.02 \mathrm{ppm}$ Se and hence animals fed on this diet were considered Se deficient animals (Group I). For Se supplemented groups, Se was added at $0.2 \mathrm{ppm}$ (Group II; adequate level) and 1ppm (Group III; excess level) as sodium selenite to Se deficient diet.
Selenium deficient diet with inactivated Baker's yeast as a protein source was prepared in the laboratory itself according to the composition given by Burk [33]. The diet contained inactivated torula yeast (inactivated by autoclaving) 30\%, sucrose $56.99 \%$, corn oil $6.67 \%$, mineral mix $5 \%$, vitamin mix $1 \%$, dl-methionine $0.3 \%$ and vitamin E $0.04 \%$. Se adequate and excess diets were prepared from Se deficient diet by supplementing it with $0.2 \mathrm{ppm}$ and $1 \mathrm{ppm}$ of Se respectively as sodium selenite. After completion of diet feeding schedule of 4 and 8 weeks, animals were sacrificed by cervical dislocation under anesthesia (50 $\mathrm{mg} / \mathrm{Kg}$ body weight of Sodium Phenobarbital), testes were removed and used for various analyses.

\subsection{Selenium estimation}

Selenium levels in testis were estimated as previously described [34]. The method is based on the principle that $\mathrm{Se}$ in tissues on acid digestion is converted into selenous acid; which on reaction with aromatic-o-diamines such as 2,3-diamine naphthalene (DAN) leads to the formation of 4,5benzopiazselenol, which displays brilliant lime green fluorescence. Briefly, 100mg of testis tissue was acid digested in concentrated $\mathrm{HNO}_{3}$ on a sand bath at approx. $100^{\circ} \mathrm{C}$ in digestion flasks fitted with long air condenser to prevent any Se vapour loss. A known amount of digest was reacted with aqueous solution of DAN (precleaned of impurities with cyclohexane). The product formed (4,5-benzopiaselenol) was extracted completely with cyclohexane and quantitated on fluorescence spectrophotometer (Perkin Elmer, USA) using $366 \mathrm{~nm}$ as excitation and $520 \mathrm{~nm}$ as emission wavelength. Sodium selenite was used as a standard for this assay.

\subsection{Biochemical estimations}

$10 \%(\mathrm{w} / \mathrm{v})$ tissue homogenates were prepared in 50mM Tris-HCl (pH 7.4) under ice-cold conditions. The homogenates were then centrifuged at $10,000 \mathrm{rpm}$ for 30 minutes. The supernatant (post mitochondrial fraction, PMF) thus obtained was collected for the biochemical estimations described below.

\subsection{Selenium Deficient Diet}




\subsection{Se-dependent glutathione peroxidase activity}

Activity of glutathione peroxidase (GSH-Px) was assayed by the coupled enzyme procedure with glutathione reductase using $\mathrm{H}_{2} \mathrm{O}_{2}$ as substrate [35]. The assay was carried out in testis PMF. The activity was expressed as $\mu$ moles of NADPH oxidized $/ \mathrm{min} / \mathrm{mg}$ protein. Total protein was estimated by the method of Lowry et al [36].

\subsection{Hormone Analysis}

Concentration of testosterone in serum was measured by DRG Testosterone ELISA. Serum concentrations of leutenizing hormone (LH) and follicle stimulating hormone $(\mathrm{FSH})$ were determined by immunoenzymometric assay (ELISCAN Diagnour).

\subsection{RNA isolation}

Total RNA was isolated from mice testis using TRI-REAGENT (Mol Res. Centre, Inc, Ohio, USA). 50mg testis tissue from different treatment groups was homogenized in $0.5 \mathrm{ml}$ of TRI-REAGENT using hand homogenizer in $1.5 \mathrm{ml}$ polystyrene microfuge tubes. The samples were kept at room temperature for 5 min after which $80 \mu \mathrm{l}$ chloroform was added. This was mixed vigorously for about $15 \mathrm{sec}$ and the homogenates were then kept at room temperature for $10 \mathrm{~min}$ followed by centrifugation at $12,000 \mathrm{rpm}$ for $15 \mathrm{~min}$ at $4^{\circ} \mathrm{C}$. Following centrifugation, the upper colorless aqueous phase containing RNA was collected. In order to precipitate RNA, isopropanol was added and after mixing, the samples were kept at room temperature for $10 \mathrm{~min}$. Thereafter, samples were spun at $12,000 \mathrm{rpm}$ for $10 \mathrm{~min}$ at $4^{\circ} \mathrm{C}$. RNA precipitate so obtained was washed by adding $75 \%$ ice-cold ethanol and spinning at $7500 \mathrm{~g}$ at $5 \mathrm{~min}$ at $4^{\circ} \mathrm{C}$. After removing the ethanol, the RNA pellet was briefly air-dried (not completely) and then dissolved in DEPC treated water. Purity, integrity and concentration of the isolated RNA were checked by taking absorbance at 260 and $280 \mathrm{~nm}$ and finding their ratio. Concentration of RNA was estimated by using $\mathrm{A}_{260}=1=40 \mu \mathrm{g} / \mathrm{ml}$.

\subsection{Primer designing and synthesis for RT-PCR analysis}

For the RT-PCR analysis, primers for the following genes i.e. CREB and CREM were searched from the literature and were got synthesized from Sigma Aldrich (USA). Primer sequences for different genes are given in Table 1.

Table 1: Sequence of Primer pairs used

\begin{tabular}{|l|l|c|}
\hline Gene & \multicolumn{1}{|c|}{ Primer Pair } & Reference \\
\hline CREB & $\begin{array}{l}\text { Sense 5' ACT GGC TTG GCA CAA CCA GA 3' } \\
\text { Antisense 5' GGC AGA AGT CTC TTC ATG ATT 3' }\end{array}$ & {$[47]$} \\
\hline CREM & $\begin{array}{l}\text { Sense 5' TGG TAA GTT GCC ATG TCA CC 3' } \\
\text { Antisense 5' ATG ACC ATG GAA ACA GTT GAA TC 3' }\end{array}$ & {$[48]$} \\
\hline $\boldsymbol{\beta}$-actin & $\begin{array}{l}\text { Sense 5' ATC CGT AAA GAC CTC TAT GC 3' } \\
\text { Antisense 5' AAC GCA GCT CAG TAA CAG TC 3' }\end{array}$ & {$[49]$} \\
\hline
\end{tabular}

\subsection{RT-PCR procedure}

RT-PCR was done using specific primers for the respective genes. RT-PCR for $\beta$-actin was also done alongwith to rule out the experimental errors. QIAZEN one step RT-PCR kit was used for the purpose. Two $\mu \mathrm{g}$ of total RNA was used in RTPCR reaction from different groups. To this, the following reagents were added as follows: $10 \mu \mathrm{l}$ $5 x$ Qiagen one step RT-PCR buffer, $2 \mu 1 \mathrm{dNTP}$ mixture, $5 \mu \mathrm{l}$ each of forward and reverse primers 
(10 $\mu \mathrm{M}$ stock), $2 \mu$ l enzyme mix, and $1 \mu \mathrm{l}$ RNase inhibitor $(1 \mathrm{U} / \mu \mathrm{l})$. Finally PCR grade RNase free water was added to make the total volume $50 \mu$ l. The components were mixed with gentle vortex and centrifuged to collect all the components at the bottom of the tube. The PCR reaction was performed in the thermal cycler (Techne Ltd, England) using following conditions: RT reaction was performed at $50^{\circ} \mathrm{C}$ for $50 \mathrm{~min}$ and activation at $94^{\circ} \mathrm{C}$ for $15 \mathrm{~min}$. PCR was followed by 35 cycles of $94^{\circ} \mathrm{C}$ (denaturation) for $45 \mathrm{sec}, 56^{\circ} \mathrm{C}$ (annealing) for $45 \mathrm{sec}, 68^{\circ} \mathrm{C}$ (extension) for $1 \mathrm{~min}$. Finally, the products were incubated at $68^{\circ} \mathrm{C}$ for 5 min to extend any incomplete single strands. To authenticate the results from RT-PCR (a semiquantitative method) analysis, initially RT-PCR for various genes was carried at 20, 25, 30, and 35 cycles. Progressive increase in products was obtained in all the cases and hence finally the RTPCR was done with the samples at 35 cycles only.

Final PCR products formed were analyzed on $1.5 \%$ agarose gel electrophoresis and densitometric analysis of the bands was done by Image J software (NIH, USA). Mean of four independent densitometric analyses of PCR product bands were determined for comparison of each analysis.

Table 2. Selenium levels and glutathione peroxidase activity in mice testis after 8 weeks of diet feeding schedule

\begin{tabular}{|c|c|c|c|}
\hline & \multicolumn{3}{|c|}{8 w eeks } \\
\hline & $\begin{array}{l}\text { Se deficient } \\
(\text { Group I) }\end{array}$ & $\begin{array}{l}\text { Se ad equate } \\
\text { (Group II) }\end{array}$ & $\begin{array}{c}\text { Se excess } \\
\text { (Group III) }\end{array}$ \\
\hline $\begin{array}{c}\text { Selenium ( } \mu \text { g Se/g } \\
\text { tissue) } \\
\text { Testis } \\
\text { Glutathione } \\
\text { peroxidase } \\
\text { ( } \mu \text { moles NADPH } \\
\text { oxid/min } / \mathrm{mg} \\
\text { protein) } \\
\text { Testis }\end{array}$ & $\begin{array}{l}0.47 \pm 0.02^{* * * *} \\
49.75 \pm 1.10^{* * * *}\end{array}$ & $\begin{array}{r}0.75 \pm 0.02 \\
116.24 \pm 3.52\end{array}$ & $0.96 \pm 0.03^{* * * *}$ \\
\hline
\end{tabular}

The values are mean $\pm S D$ of four independent observations. *, **, *** represent $p<0.05, p<0.01, p<0.001$, respectively.

\subsection{Quantitation of CREB and CREM in testis by ELISA}

$10 \%(\mathrm{w} / \mathrm{v})$ tissue homogenates were prepared in $50 \mathrm{mM}$ Tris- $\mathrm{HCl}(\mathrm{pH} 7.4)$ under ice-cold conditions. The homogenates were then centrifuged at 10,000rpm for 30 minutes. The supernatant (post mitochondrial fraction, PMF) thus obtained was quantitated for protein by Lowry method and collected for ELISA. $2.5 \mu \mathrm{g}$ protein was loaded onto ELISA strip wells in carbonate buffer and kept overnight at $4^{\circ} \mathrm{C}$. The wells were then blocked with $1 \% \mathrm{BSA}$ for $1 \mathrm{hr}$ at $37^{\circ} \mathrm{C}$. After washings with PBS- Tween20, the wells were incubated with respective primary antibodies $(1: 500)$ for $2 \mathrm{hrs}$ at $37^{\circ} \mathrm{C}$. After washings, the wells were incubated with secondary antibody $(1: 500)$ for $2 \mathrm{hrs}$ at $37^{\circ} \mathrm{C}$. Then the substrate, 2,2'-azino-di-3-ethylbenzthiazoline 
sulfonic acid (ABTS) in citrate buffer was added along with $\mathrm{H}_{2} \mathrm{O}_{2}$ and kept in dark for 20 mins. The color obtained was quantitated at $405 \mathrm{~nm}$.

\subsection{Light Microscopy}

Testes were fixed immediately in Zenker's fixative. Next, the tissue was dehydrated in ascending series of alcohol $(30 \%, 50 \%, 70 \%, 90 \%$ and $100 \%$ ) for $1 \mathrm{hr}$ each. Traces of mercury were removed by placing the tissue pieces in iodine solution (prepared in 70\% alcohol) during dehydration at $70 \%$ alcohol level. For embedding, the dehydrated samples were placed in benzene (30min), then sequentially in 1:1 benzene: wax (1hr) and then given two changes of $1 \mathrm{hr}$ each in pure wax before finally embedding in wax. $5 \mu \mathrm{m}$ thick sections were obtained using a manual hand driven microtome and transferred to the glass slides. These were dewaxed in xylene, rehydrated in descending series of alcohol and stained with haematoxylin and eosin (H and E). Stained sections were mounted in DPX after dehydration and viewed under a light microscope.

\subsection{Statistical analysis}

The difference between Means \pm Standard Deviations (SD) for control and treated groups were examined by using the Student's t-test for unpaired values. Statistical difference of $p$-value at the level of 0.05 or less was considered significant.

\section{Results}

\subsection{Selenium levels}

Selenium was estimated in the testis of mice from all the treatment groups after 8 weeks of diet feeding (Table 2). In testis, a significant decrease in Se levels was observed in Se deficient group I $(p<0.001)$ as compared to the respective $\mathrm{Se}$ adequate group II after 8 weeks of diet feeding schedule. However, significant increase in $\mathrm{Se}$ levels was observed in the $\mathrm{Se}$ excess supplemented group III $(\mathrm{p}<0.001)$ as compared to the respective Se adequate group II (Table 2).

Table 3. Protein expression of CREB and CREM by ELISA after 8 weeks of diet feeding schedule

\begin{tabular}{|c|c|c|c|}
\hline & Se Deficient & Se Ad equate & Se Excess \\
\hline $\begin{array}{c}\text { CREB } \\
\text { (405nm) }\end{array}$ & $0.281 \pm 0.01^{* * * *}$ & $0.642 \pm 0.01$ & $0.314 \pm 0.01^{* * * *}$ \\
\hline $\begin{array}{c}\text { CREM } \\
\text { (405nm) }\end{array}$ & $0.235 \pm 0.01^{* * * *}$ & $0 . .762 \pm 0.01$ & $0.278 \pm 0.01^{* * * *}$ \\
\hline
\end{tabular}

The values are mean $\pm S D$ of six independent observations. *, **, *** represent $p<0.05, p<0.01, p<0.001$, respectively.

\subsection{Glutathione Peroxidase (GSH-Px)}

GSH-Px activity was measured in testis (Table 2). A significant decrease $(\mathrm{p}<0.001)$ was observed in the selenium deficient group I when compared to the selenium adequate group II. On the contrary, significant increase was observed in selenium excess group III $(\mathrm{p}<0.001)$ as compared to the selenium adequate group II.

\subsection{Hormone Analysis}

Significant decrease in the levels of serum testosterone and FSH was observed in selenium deficient and selenium excess group after 8 weeks of diet feeding schedule (Table 3).

Similarly, after 8 weeks of selenium deficient and selenium excess diet feeding in separate groups, significant reduction the levels of serum LH was observed. 
Table 4. Changes in the levels of serum Testosterone, LH and FSH after 8 weeks of diet feeding schedule

\begin{tabular}{|c|c|c|c|}
\hline & Se D eficien t & Se Ad equate & Se Excess \\
\hline $\mathrm{T}(\mathrm{n} \mathrm{g} / \mathrm{ml})$ & $0.44 \pm 0.01^{* * * * *}$ & $0.68 \pm 0.01$ & $0.46 \pm 0.02^{* 3 * * k}$ \\
\hline $\mathrm{LH}(\mathrm{ng} / \mathrm{m} \mathbf{l})$ & $1.2 \pm 0.01^{* * * * *}$ & $2.4 \pm 0.03$ & $1.5 \pm 0.01^{* * * * *}$ \\
\hline $\operatorname{FSH}(\mathrm{ng} / \mathrm{ml})$ & $0.4 \pm 0.02^{* 3 * * k}$ & $0.58 \pm 0.02$ & $0.46 \pm .001^{* * * *}$ \\
\hline
\end{tabular}

The values are mean $\pm S D$ of six independent observations. *, **, *** represent $p<0.05, p<0.01, p<0.001$, respectively

(a)

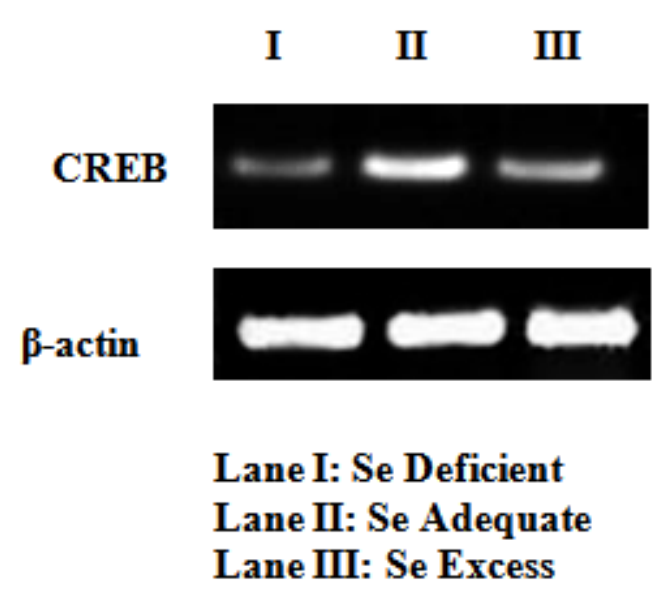

(b)

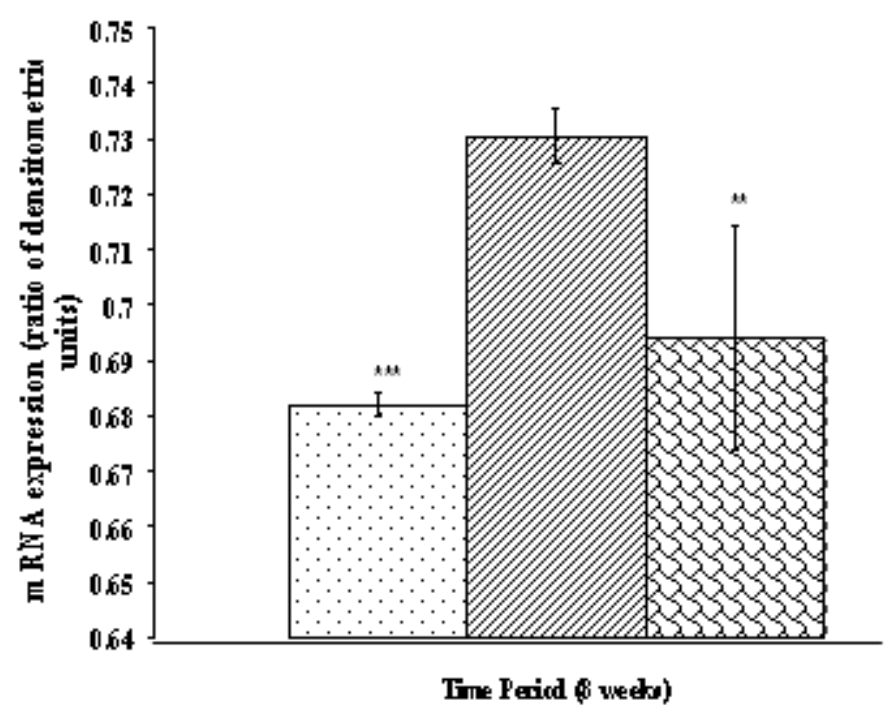

Figure 1. Effect of modulation in selenium status on the mRNA expression of CREB (a) and its densitometric analysis. (b) Lane I- Se Deficient (8 weeks), Lane II- Se Adequate (8 Weeks), Lane III- Se Excess (8 Weeks). The values are mean $\pm \mathrm{SD}$ of four independent observations. *, **, *** represent $\mathrm{p}<0.05, \mathrm{p}<0.01, \mathrm{p}<0.001$, respectively.

\section{4 mRNA expression studies}

Total RNA preparation was quantitated by finding the $\mathrm{A}_{260}$ and quality of RNA was also checked by finding the $\mathrm{A}_{260} / \mathrm{A}_{280}$ which was found to be near 1.9. RT-PCR was initiated with the expression of the products of $\beta$-actin in total RNA in all the treatment groups at both the intervals. No change in the expression of the mRNA was observed in all the treatment groups.

RT-PCR products and their densitometric analysis for CREB are represented in Fig 1a, b. There was a significant decrease in the mRNA expression of CREB in the Se deficient group as compared to the Se adequate group at both the treatment intervals. Similarly decrease in 
expression was also observed in Se excess group as compared to the Se adequate diet fed group.

CREM gene expression and densitometric analysis of RT-PCR products are shown in Fig 2a,b. There was a significant decrease in the mRNA expression of CREM in the Se deficient as well as Se excess group as compared to $\mathrm{Se}$ adequate group at 8 weeks of diet feeding.

\subsection{Protein expression studies}

CREB and CREM were quantitated in the PMF of testis in various groups of treated animals using ELISA. Progressive significant decrease in the levels of CREB and CREM was observed in Se deficient and excess groups as compared to $\mathrm{Se}$ adequate group (Table 4).

\subsection{Histological studies}

Histological changes in the testis after haematoxylin and eosin ( $\mathrm{H}$ and $\mathrm{E})$ staining of the paraffin sections was studied in all the treatment groups (Fig 3).

Mice fed Se adequate diet (group II) showed normal testicular histology (Fig 3b). All the stages of transformation of seminiferous epithelia from spermatogonia to mature spermatozoa were seen in the tubules of mice fed diet containing adequate levels of Se for 8 weeks.

Shrinkage of the seminiferous tubules was evident in Se deficient group I (Fig 3a) compared to its respective Se adequate group II (Fig 3b). Basement membrane was intact but the germ cell height was reduced. The lumen was almost completely devoid of spermatozoa. In Se excess group III (Fig 3c) shrinkage of the seminiferous tubules was observed with disorganization of germ cells. The lumen size was reduced and appeared almost completely devoid of spermatozoa. (a)

I II III

CREM

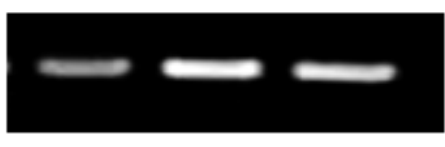

$\beta$-actin

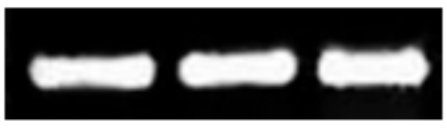

Lane I: Se Deficient

Lane II: Se Adequate

Lane III: Se Excess (b)

QSeDeficient USe Adequat BSe Evoss

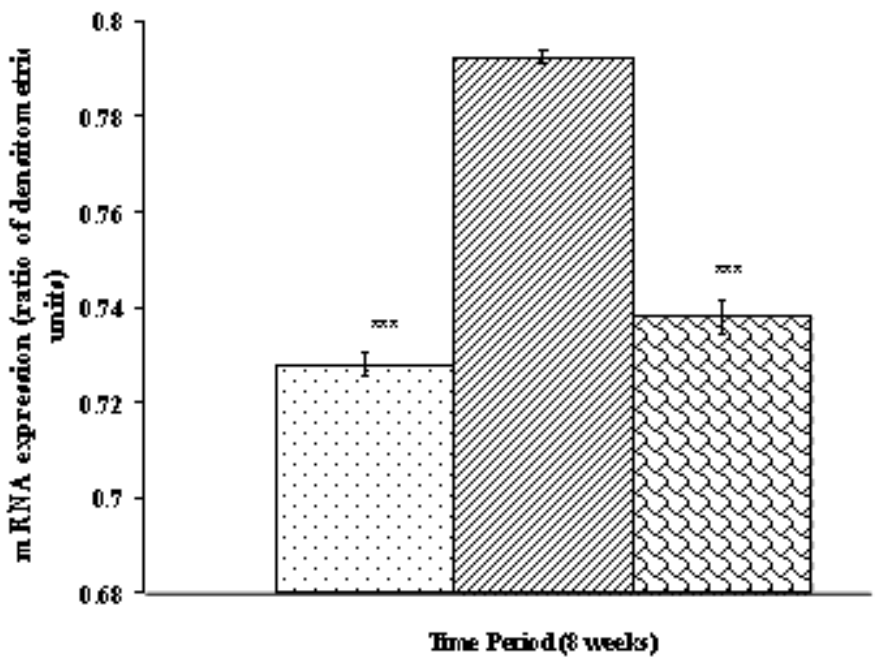

Figure 2. Effect of modulation in selenium status on the mRNA expression of CREM (a) and its densitometric analysis. (b) Lane I- Se Deficient (8 weeks), Lane II- Se Adequate (8 Weeks), Lane III- Se Excess (8 Weeks). The values are mean $\pm \mathrm{SD}$ of four independent observations. $*, * *, * *$ represent $\mathrm{p}<0.05, \mathrm{p}<0.01, \mathrm{p}<0.001$, respectively.

\section{Discussion}

The present study aimed at exploring further the molecular mechanism involved behind regulation of spermatogenesis by Se. The establishment of Se status in the animals under study was confirmed by measuring the testicular Se levels and the enzyme activity if glutathione peroxidase, GSH-Px. 
A decrease in Se levels in Se deficient group and an increase in the Se excess group confirmed the establishment of Se status in the animals, as

(a)

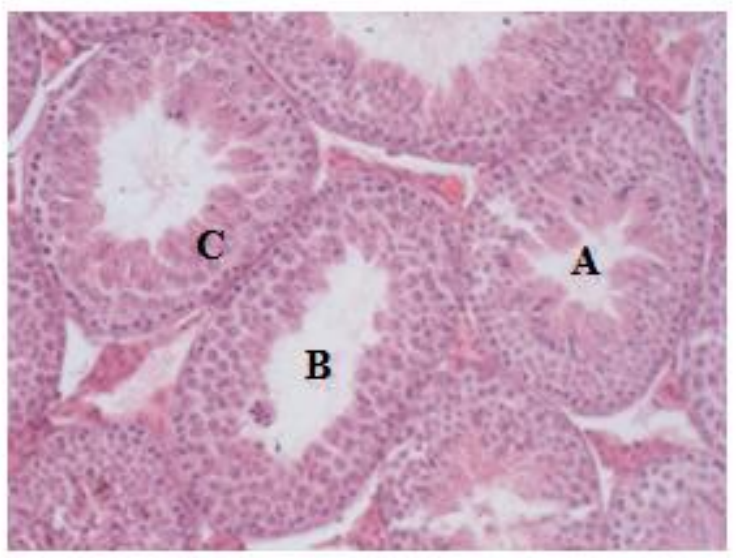

(b)

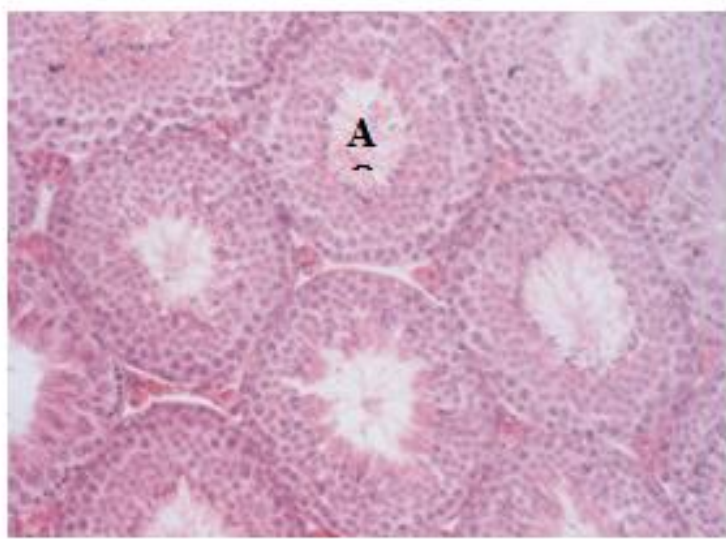

(c)

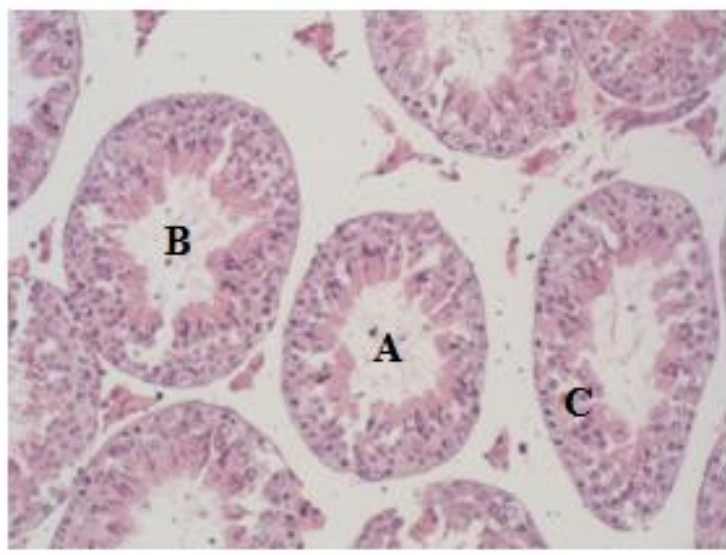

also reported elsewhere by previous work from our laboratory [29].

A- Star shaped lumen

B- Enlarged lumen devoid of spermatozoa

C- Displacement of germ cells and decrease in germ cell height

\section{A- Normal histoarchitecture. All stages of seminiferous epithelium from spermatogonia to mature spermatozoa can be seen.}

\section{A- Shrinkage of seminiferous tubules \\ B- Lumen devoid of spermatozoa \\ C-Displacement of germ cells and decrease in germ cell height}

Figure 3. Photomicrograph showing H/E staining in testis paraffin sections of mice fed respective diet for 8 weeks. a)Se Deficient (8 weeks), b)- Se Adequate (8 weeks), c)- Se Excess (8 weeks).

GSH-Px activity decreased in Se deficient group. Decreased Se levels [29] concomitant with the decrease in GSH-Px activity might contribute to building up of oxidative stress in this group. In Am. J. Biomed. Sci. 2010, 2(4), 329-341; doi: 10.5099/aj100400329
Se excess group, increase in GSH-Px activity was observed after 8 weeks interval.

After 8 weeks of Se deficient and excess diet feeding schedule, the hormonal analysis revealed (c) 2010 by NWPII. All rights reserved. 
decrease in the levels of LH, FSH and Testosterone. It has been reported that the entire process of spermatogenesis is regulated by gonadotropins released from the pituitary gland and sex steroids produced within the testis - the pituitary-testicular axis [1]. Alteration of this regulation results in profound changes in testicular morphology and sperm production [37]. In the present study, altered $\mathrm{Se}$ status could be responsible for change in the levels of these hormones, which finally culminates in altered testicular morphology as demonstrated in the present study.

The binding of the glycoprotein FSH to receptors on Sertoli cells stimulates adenylyl cyclase, causing an increase in intracellular levels of cAMP [38]. An increase of intracellular cAMP results in the activation of cAMP dependent protein kinase $\mathrm{A}$, which phosphorylates the cAMP regulatory element-binding protein (CREB). mRNA expression analysis revealed decreased expression of CREB in Se deficient and excess groups. This decrease could be explained on the basis of decrease in the FSH levels observed under Se status conditions; following decrease in FSH levels, cAMP dependent protein kinase A was not activated, thus phosphorylation of CREB was not achieved.

Also, significant decrease in the mRNA expression of CREM was observed in Se deficient and excess groups in the present study. It has been reported that male mice lacking a functional CREM gene are infertile due to round spermatid maturation arrest [13, 14], suggesting that CREM is important for male fertility. CREM expression in male germ cells is phosphorylation independent and is achieved by ACT-Activator of CREM in testis [39]. It was found that ACT mRNA expression decreased in Se deficient and excess groups (data not shown). ACT is absent or at least drastically reduced in mice lacking a functional CREM gene and in men with round spermatid maturation arrest, in which CREM has been demonstrated to be only barely detectable or completely absent [40]. This observation also suggests that CREM plays an important role in ACT transcriptional regulation.

Transcription factor CREM is also involved in increase in steroid synthesis which is essential for steroid hormone synthesis [41]. Thus, the decrease in the levels of testosterone, $\mathrm{LH}$ and $\mathrm{FSH}$ in Se deficient and excess groups could also be explained on the basis of decrease in CREM expression in these groups.

It has been shown previously that [42] male mice lacking CREM expression are sterile because of stage-specific arrest of sperm maturation as the spermatids undergo apoptosis. A role for CREB in nerve growth factor-dependent survival has been clearly demonstrated for the sensory ganglia [43]. In vitro experiments performed on postnatal sympathetic neuronal cultures indicated that nerve growth factor-dependent survival requires CREBmediated gene expression. Also, it has been demonstrated that germ and sertoli cell apoptosis is induced by withdrawl of FSH and Testosterone respectively [44].

Previous studies in our laboratory [26,27] have demonstrated that Se deficient and excess conditions modulated the intracellular transcription factors and stress activated protein kinases that finally culminated in the induction of testicular apoptosis resulting in diminished reproductive potential of male mice.

The results obtained in the present study are in agreement with the previous work suggesting that spermatogenesis is altered by alteration in $\mathrm{Se}$ status. The altered Se status lead to changes in the levels of steroid hormones and the testicular circuitry was hampered. This lead to changes in the basal transcription machinery as demonstrated previously and in addition, the transcription factor CREB and CREM also showed changes in their expression.

Thus, the study lead to a conclusion that spermatogenesis is a developmentally regulated program, and is under the control of complex hormonal circuitary which leads to modulation in the various signaling pathways governing cell survival and apoptosis depending upon the physiological conditions.

\section{Acknowledgement}

Authors acknowledge the financial support provided by Indian Council of Medical Research, Govt of India, New Delhi (India). Authors also acknowledge the help and advice provided by Dr. 
T. Mukhopadhyay, Director, National Centre for Human Genome Studies and Research, Chandigarh (India).

\section{References}

1. Griswold, M.D. The central role of sertoli cells in spermatogenesis, Semin Cell Dev Biol, 1998, 9, 411-416.

2. Walker,W.H.; Habener, J.F. Role of transcription factors CREB and CREM in cAMP-regulated transcription during spermatogenesis, Trends Endocrinol Metab, 1996, 7, 133-138.

3. Scobey,M.J.; Bertera, S.; Somers, J.P.; Watkins, S.C.; Zeleznik, A.J.; Walker, W.H. Delivery of a cyclic adenosine 39,59monophosphate response element binding protein (CREB) to seminiferous tubules results in impaired spermatogenesis, Endocrinology, 2001, 142, 948-954.

4. De Cesare, D.; Fimia, G.M.; Sassone-Corsi, P. Signaling routes to CREM and CREB: plasticity in transcriptional activation, Trends Biochem Sci, 1999, 24, 281-285.

5. Gonzalez, G.A.; Montminy, M.R. Cyclic AMP stimulates somatostatin gene transcription by phosphorylation of CREB at serine 133, Cell, 1989, 59, 675-680.

6. Hoeffler, J.P.; Meyer, T.E.; Waeber, G.; Habener, J.F. Multiple adenosine 30, 50monophosphate response element DNAbinding proteins generated by gene diversification and alternative exon splicing, Molecular Endocrinology, 1990, 4, 920-930.

7. Ruppert, S.; Cole, T.J.; Boshart, M.; Schmid, E.; Schutz, G. Multiple mRNA isoforms of the transcription activator protein CREB: generation by alternative splicing and specific expression in primary spermatocytes, EMBO Journal, 1992 11, 1503-1512.

8. Waeber, G.; Meyer, T.E.; LeSieur, M.; Hermann, H.L.; Gerard, N.; Habener, J.H. Developmental stage-specific expression of cyclic adenosine 3',5'- monophosphate response element binding protein CREB during spermatogenesis involves alternative exon splicing, Molecular Endocrinology, 1993, 7, 1501-1513.

9. Daniel, P.B.; Habener, J.F. Cyclical alternative exon splicing of transcription factor cyclic adenosine monophosphate response elementbinding protein (CREB) messenger ribonucleic acid during rat spermatogenesis, Endocrinology, 1998, 139, 3721-3729.

10. Delmas, V.; van der Hoorn, F.; Mellstrom, B.; Jegou, B,; Sassone-Corsi, P. Induction of CREM activator proteins in spermatids: downstream targets and implications for haploid germ cell differentiation, Mol Endocrinol, 1993, 7,1502-1514.

11. Krausz, C.; Sassone-Corsi, P. Genetic control of spermiogenesis: insights from the CREM gene and implications for human infertility, Reprod Biomed Online, 2005, 10, 64-71.

12. Hogeveen Kevin, N.; Sassone-Corsi, P. Regulation of gene expression in post-meiotic male germ cells: CREM-signalling pathways and male fertility, Human fertility (Cambridge, England), 2006, 9, 73-79.

13. Blendy, J.A.; Kaestner, K.H.; Weinbauer, G.F.; Nieschlag, E.; Schutz, G. Severe impairment of spermatogenesis in mice lacking the CREM gene, Nature 1996, 380, 162-165.

14. Nantel, F.; Monaco, L.; Foulkes, N.S.; Masquilier, D.; LeMeur, M.; Hensiksen, K.; Dierich, A.; Parvinen, M.; Sassone-Corsi, P. Spermiogenesis deficiency and germ-cell apoptosis in CREM-mutant mice, Nature, 1996, 380, 159-162.

15. Sassone- Corsi, P. Coupling gene expression to cAMP signaling: Role of CREB and CREM, Int J Biochem Cell Biol, 1998, 30, 27 38.

16. Montminy, M. Transcriptional regulation by cyclic AMP, Annu Rev Biochem, 1997, 66, 807-822.

17. Sassone-Corsi, P. Transcription factors responsive to cAMP, Annu Rev Cell Dev Biol, 1997, 11, 355-377.

18. Bhasin, S.; Mallidis, C.; Ma, K. The genetic basis of infertility in men, in: Holly JMP, F. C. $\mathrm{W}$. Wu (eds.), Clinical Endocrinology and 
Metabolism, 2000, vol. 14, 363-388, London: Harcourt Publishers Ltd.

19. Bhasin, S.; Ma, K.; Sinha, I.; Limbo, M.; Taylor, W.E.; Salehian, B. The genetic basis of male infertility, Endocrinol Metab Clin North Am, 1998, 27, 783-805.

20. McLachlan, R.I. The endocrine control of spermatogenesis, in: Holly JMP, F. C. W. Wu (eds.), Clinical Endocrinology and Metabolism, 2000, vol. 14, 345-362, London: Harcourt Publishers Ltd.

21. Giwercman, A.; Bonde, J.P. Declining male fertility and environmental factors, Endocrinol Metab Clin North Am, 1998, 27, 807-830.

22. Sharpe, R.M. Environment, lifestyle and male infertility, in: Holly JMP, F. C. W. Wu (eds.), Clinical Endocrinology and Metabolism, 2000, vol. 14, 489-503, London: Harcourt Publishers Ltd.

23. Borek, C.; Ong, A.; Mason, H.; Donahue, L.; Biaglow, J.E. Selenium and vitamin E inhibit radiogenic and chemically induced transformation in vitro via different mechanisms, Proc Natl Acad Sci USA, 1986, 83, 1490-1494.

24. Zhuang, S.; Demirs, J.T.; Kochevar, I.E. p38 Mitogen-activated protein kinase mediates Bid cleavage, mitochondrial dysfunction, and caspase-3 activation during apoptosis induced by singlet oxygen but not by hydrogen peroxide, J Biol Chem, 2000, 275, 2593925948.

25. Ranawat, P.; Bansal, M.P. Decreased glutathione levels potentiate the apoptotic efficacy of selenium: possible involvement of p38 and JNK MAPKs- in vitro studies, Mol Cell Biochem, 2008, 309, 21-32.

26. Ranawat, P.; Bansal, M.P. Apoptosis induced by modulation in selenium status involves p38 MAPK and ROS: implications in spermatogenesis, Mol Cell Biochem, 2009, 330, 83-95.

27. Ranawat, P.; Bansal, M.P. Delineating the Molecular Mechanism behind Regulation of Spermatogenesis by Selenium: Involvement of Mitogen Activated Protein Kinase; JNK, Am J Biomed Sci, 2009, 1, 226-241.

28. Shalini, S.; Bansal, M.P. Role of selenium in regulation of spermatogenesis: involvement of activator protein 1, Biofactors, 2005, 23, 151-162.

29. Shalini, S.; Bansal, M.P. Alterations in selenium status influences reproductive potential of male mice by modulation of transcription factor NFkappaB, Biometals, 2007, 20, 49-59.

30. Behne, D.; Hilmert, H.; Scheid, S.; Gessner, H.; Elger, W. Evidence for specific selenium target tissues and new biologically important selenoproteins, Biochem Biophys Acta, 1998, 966, 12-21.

31. Shalini, S.; Bansal, M.P. Dietary selenium deficiency as well as excess supplementation induces multiple defects in mouse epididymal spermatozoa: understanding the role of selenium in male fertility, Int J Androl , 2008, 31, 438-449.

32. Shen, H.M.; Yang, D.F.; Ong, D.N. Induction of oxidative stress and apoptosis in sodium selenite-treated human hepatoma cells (HepG2), Int J Cancer, 1999, 81, 820-828.

33. Burk, R.F. Production of selenium deficiency in rat, Method Enzymol, 1987, 143, 307-313.

34. Hasunuma, R.; Ogawi, T.; Kawaniska, Y. Fluorometric determination of selenium in nanogram amounts in biological materials using 2,3-diaminonaphthalene, Anal Biochem, 1982, 126, 242-245.

35. Paglia, D.E.; Valentine, W.N. Studies on the quantitative and qualitative characterization of erythrocyte glutathione peroxidase, J Lab Clin Med, 1967, 70, 158-168.

36. Lowry, O.H.; Rosebrough, N.J.; Farr, A.L.; Randall, R.J. Protein measurement with Folin phenol reagent, J Biol Chem, 1951, 193, 265275.

37. Mclean, D.J.; Friel, P.J.; Pouchnik, D.; Griswold, M.D. Oligonucleotide Microarray Analysis of Gene Expression in FollicleStimulating Hormone-Treated Rat Sertoli Cells, Molecular Endocrinology, 2002, 16, 2780-2792.

38. Richards, J.S. New signaling pathways for hormones and cyclic adenosine 3', 5'monophosphate action in endocrine cells, Mol Endocrinol, 2001, 15, 209-218.

39. Fimia, G.M.; de Cesare, D.; Sassone-Corsi, P. CBP- independent activation of CREM and

(C) 2010 by NWPII. All rights reserved. 
CREB by the LIM-only protein ACT, Nature, 1999, 398, 165-169.

40. Steger, K.; Klonisch, T.; Gavenis, K.; Behr, R.; Schaller, V.; Drabent, B.; Doenecke, D.; Nieschlag, E.; Bergmann, M.; Weinbauer, G.F. Round spermatids show normal testis-specific $\mathrm{H} 1 \mathrm{t}$ but reduced cAMP-responsive element modulator and transition protein 1 expression in men with round spermatid maturation arrest, J Androl, 1999, 20, 747-754.

41. Manna, P.R.; Tena-Sempere, M.; Huhtaniemi, I.T. Molecular mechanisms of Thyroid hormone -stimulated steroidogenesis in mouse leydig tumor cells. Involvement of the steroidogenic acute regulatory protein, J Biol Chem, 1999, 274, 5909.

42. Beissbarth, T.; Borisevich, I.; Horlein, A.; Kenzelmann, M.; Hergenhahn, M..; KleweNebenius, A.; Klaren, R.; Korn, B.; Schmid, W.; Vingron, M.; Schutz, G. Analysis of CREM-dependent gene expression during mouse spermatogenesis, Mol Cell Endocrinol, 2003, 212, 29-39.

43. Lonze, B.E.; Riccio, A.; Cohen, S.; Ginty, D.D. Apoptosis, axonal growth defects, and degeneration of peripheral neurons in mice lacking CREB, Neuron, 2002, 34, 371-385.
44. Tesarik, A.; Guido, M.; Mendoza, C.; Greco, E. Human spermatogenesis in vitro: respective effects of follicle stimulating hormoneand testosterone on meiosis, spermiogenesis and sertoli cell apoptosis, J Clin Endocrinol Metab, 1998, 83, 4467-4473.

45. Rudolph, D.; Tafuri, A.; Gass, P.; Hammerling, G.J.; Arnold, B.; Schutz, G. Impaired Fetal $\mathrm{T}$ Cell Development and Perinatal Lethality in Mice Lacking the cAMP Response Element Binding Protein, Proc Natl Acad Sci USA, 1998, 95, 4481-4486.

46. Behr, R.; Hunt, N.; Ivell, R.; Wessels, J.; Weinbauer, G.F. Cloning and Expression Analysis of Testis-Specific Cyclic 3',5'Adenosine Monophosphate-Responsive Element Modulator Activators in the Nonhuman Primate (Macaca fascicularis): Comparison with Other Primate and Rodent Species, Biology of Reproduction, 2000, 62, 1344-1351.

47. Yamada, K.; Takane-Gyotoku, N.; Yuan, X.; Ichikawa, F.; Inada, C.; Nonaka, K. Mouse islet cell lysis mediated by interleukin-1induced Fas, Diabetologia, 1996, 39, 13061312. 